OPEN ACCESS

Edited by:

Valerie Kouskoff,

The University of Manchester,

United Kingdom

Reviewed by:

Philippe Bourin,

Univercell-Biosolutions, France

Akiyoshi Uezumi,

Tokyo Metropolitan Institute

of Gerontology, Japan

${ }^{*}$ Correspondence:

Helen C. O'Neill

honeill@bond.edu.au

Specialty section:

This article was submitted to

Stem Cell Research,

a section of the journal

Frontiers in Cell and Developmental

Biology

Received: 02 October 2018

Accepted: 08 January 2019

Published: 24 January 2019

Citation:

Lim HK and O'Neill HC (2019)

Identification of Stromal Cells

in Spleen Which Support

Myelopoiesis.

Front. Cell Dev. Biol. 7:1.

doi: 10.3389/fcell.2019.00001

\section{Identification of Stromal Cells in Spleen Which Support Myelopoiesis}

\author{
Hong Kiat Lim ${ }^{1,2}$ and Helen C. O’Neill ${ }^{*}$ \\ ${ }^{1}$ Clem Jones Centre for Regenerative Medicine, Faculty of Health Sciences and Medicine, Bond University, Gold Coast, \\ QLD, Australia, ${ }^{2}$ Research School of Biology, Australian National University, Canberra, ACT, Australia
}

Stromal cells in spleen organize tissue into red pulp, white pulp and marginal zone, and also interact with hematopoietic cells to regulate immune responses. This study has used phenotypic information of a previously described spleen stromal cell line called 5G3, which supports restricted hematopoiesis in vitro, to identify an equivalent stromal cell subset in vivo and to test its capacity to support hematopoiesis. Using stromal cell fractionation, phenotypic analysis, as well as cell growth and hematopoietic support assays, the Sca- $1^{+} \mathrm{gp} 38^{+}$Thy $1.2^{+} \mathrm{CD} 29^{+} \mathrm{CD} 51^{+}$fraction of spleen stroma has been identified as an equivalent stromal subset resembling the 5G3 cell counterpart. While heterogeneity may still exist within that subset, it has been shown to have superior hematopoietic support capacity compared with the 5G3 cell line, and all other spleen stromal cell fractions tested.

Keywords: hematopoiesis, stroma, spleen, myelopoiesis, microenvironment

\section{INTRODUCTION}

Stromal cells of mesenchymal lineage represent a supporting cellular network forming the basement layer in tissue and contributing to organ architecture and function (Mueller and Germain, 2009; Roozendaal and Mebius, 2011). In the case of spleen, distinct stromal cells are identifiable in the regions of red pulp, white pulp and marginal zone. So far, several distinct mesenchymal stromal cell types have been described in spleen. Splenic fibroblastic reticular cells assist in regulating immune responses through secretion of chemokines like CCL19 and CCL21 (Luther et al., 2000). Others include gp $38^{+}$fibroblastic reticular cells, MadCAM1 ${ }^{+}$marginal reticular cells, $\mathrm{CD} 35^{+}$follicular dendritic cells, $\mathrm{CD} 105^{+}$red pulp fibroblasts and $\mathrm{CD} 31^{+}$vascular endothelial cells (Mueller and Germain, 2009; den Haan et al., 2012).

Many studies have investigated the function of splenic stroma in immune regulation (Malhotra et al., 2013), but limited studies have addressed their hematopoietic support capacity. The perception in the field is that extramedullary hematopoiesis occurs in spleen with stress or disease. However, questions remain about the role of spleen in steady-state hematopoiesis (Kim, 2010; Johns and Christopher, 2012). A role for spleen in hematopoiesis has been clearly defined in mice, and several studies now indicate the presence of hematopoietic stem cells (HSC) in spleen of several species including humans (Dor et al., 2006; Tan and O'Neill, 2010; Inra et al., 2015). Definition of a role for spleen in hematopoiesis would offer tremendous clinical potential, and the substantial knowledge of bone marrow hematopoiesis could easily be directed to a study of hematopoiesis in spleen. Furthermore, there has been no in-depth analysis of splenic stroma which could be candidate elements for HSC niches. 
Previously, we described a cloned stromal cell line called 5G3 which is unique in its ability to support in vitro hematopoiesis. When $5 \mathrm{G} 3$ stroma was overlaid with bone marrow progenitors, transient production of myeloid and conventional dendritic-like cells (cDC) was reported, as well as the continuous production of a specific dendritic-like cell called 'L-DC' (Periasamy et al., 2009; Petvises and O'Neill, 2014a,b). The cDC-like cells were recently identified as regulatory DC (Petvises et al., 2018). Several studies also identified the maintenance of progenitors within cocultures (Tsuchiyama et al., 1995; Corselli et al., 2013; Petvises and O'Neill, 2014a), and the ability to achieve L-DC production through overlay of HSC or multipotential progenitors (MPP) above stroma (Hinton et al., 2011; Petvises and O’Neill, 2014b). Longterm stromal cocultures maintain HSPC and this has been demonstrated through in vivo reconstitution assays (O'Neill et al., 2014). The $5 \mathrm{G} 3$ splenic stromal line expresses mesenchymal markers like CD140a, CD51, CD29, gp38, Thy1, Sca-1, and CD105 (Lim et al., 2018). Attempts have been made here to isolate an in vivo equivalent stromal cell subset to $5 \mathrm{G} 3$ and to compare its hematopoietic support capacity with other stromal fractions. This study uses marker analysis to define stromal subsets in spleen and to assess their capacity for in vitro growth. It also identifies subsets which support hematopoiesis which could represent candidate niche elements for hematopoiesis in spleen. This in vivo study therefore provides physiological relevance to studies describing in vitro hematopoiesis.

\section{MATERIALS AND METHODS}

\section{Animals}

Specific pathogen-free C57BL/6J ( $H-2 K^{\mathrm{b}}$ : CD45.2) mice aged 6 days or 4-8 weeks were obtained from the John Curtin School of Medical Research (JCSMR: Canberra, ACT, Australia). Mice were housed and handled according to protocols approved by the Animal Experimentation Ethics Committee at the Australian National University (ANU: Canberra, ACT, Australia).

\section{Cell Cultures}

The 5G3 stroma was derived from the STX3 splenic stromal line by single-cell cloning and freezing down (Despars and O’Neill, 2006a,b; Despars et al., 2008). Cells were cultured at $37^{\circ} \mathrm{C}$ in $5 \% \mathrm{CO}_{2}$ in air with $95 \%$ humidity in supplemented Dulbecco's modified Eagle's medium (Sigma-Aldrich: Castle Hill, NSW, Australia) containing $10 \%$ fetal calf serum, $5 \times 10^{-4} \mathrm{M} 2$ mercaptoethanol, $10 \mathrm{mM}$ HEPES, $100 \mathrm{U} / \mathrm{ml}$ penicillin, $100 \mu \mathrm{g} / \mathrm{ml}$ streptomycin, $4 \mathrm{mg} / \mathrm{L}$ glucose, $6 \mathrm{mg} / \mathrm{L}$ folic acid, $36 \mathrm{mg} / \mathrm{L} \mathrm{L}-$ asparagine, $116 \mathrm{mg} / \mathrm{l} \mathrm{L}$-asparagine hydrochloric acid (sDMEM). Stromal cells were passaged twice by transferring scraped cells into new flasks before use in experiments.

\section{Fractionation of Bone Marrow Progenitors}

Methods for isolation of bone marrow progenitors have been described (Periasamy et al., 2013; Petvises and O'Neill, 2014a). Bone marrow cells were flushed from femurs of C57BL/6J adult mice. Red blood cells were selectively lysed using lysis buffer. MACS $^{\circledR}$ magnetic bead technology (Miltenyi Biotec: Gladbach, Germany) was used to deplete lineage-specific hematopoietic cells. The process involved labeling cells with a cocktail of lineagespecific biotinylated antibodies with specificity for NK1.1, CD11b, CD11c, Gr-1, MHC-II, Ter119, CD3 and CD19, followed by anti-biotin microbeads, which were captured in LS or MS columns (Miltenyi Biotec). Lin ${ }^{-}$bone marrow progenitors were eluted and collected.

\section{Dissociation of Splenic Stromal Cells}

Murine adult or 6 day old spleens were dissociated by pressing between microscope slides before filtering through a $70 \mu \mathrm{m}$ strainer. The stromal fraction was collected in a tube containing $2 \mathrm{ml}$ collagenase IV extraction buffer [( $2 \%$ fetal calf serum, $1 \mathrm{mg} / \mathrm{ml}$ collagenase IV (Sigma-Aldrich) and $40 \mu \mathrm{g} / \mathrm{ml}$ DNase I (Sigma-Aldrich) in RPMI] and incubated for $20 \mathrm{~min}$ at $37^{\circ} \mathrm{C}$ with rotation. Two $\mathrm{ml}$ collagenase $\mathrm{D}$ extraction buffer $[2 \%$ fetal calf serum, $1 \mathrm{mg} / \mathrm{ml}$ collagenase D (Roche Applied Science: North Ryde, NSW, Australia) and $40 \mu \mathrm{g} / \mathrm{ml}$ DNase I in RPMI] was added for another $20 \mathrm{~min}$ incubation at $37^{\circ} \mathrm{C}$ with rotation. An additional $2 \mathrm{ml}$ of collagenase $\mathrm{D}$ extraction buffer was added and the cell suspension incubated for $20 \mathrm{~min}$ at $37^{\circ} \mathrm{C}$ with rotation. The activity of collagenase was halted by addition of $60 \mu \mathrm{L}$ of $500 \mathrm{mM}$ EDTA to give a final concentration of $5 \mathrm{mM}$. Digested spleens were washed twice with $5 \mathrm{ml} \operatorname{sDMEM}\left(300 \mathrm{~g}, 4^{\circ} \mathrm{C}, 5 \mathrm{~min}\right)$, and viable cell count determined using trypan blue staining. The cell pellet was resuspended in $1 \mathrm{ml}$ sDMEM for antibody staining, flow cytometric analysis and sorting.

\section{Antibody Staining and Flow Cytometric Analysis}

The procedures used to stain cells and assess antibody binding have been described (Periasamy et al., 2009; Periasamy and O'Neill, 2013; Petvises and O’Neill, 2014b). Antibodies used were specific for CD11b (clone M1/70), CD11c (N418), NK1.1 (PK136), Gr-1 (RM6-8C5), Ter119 (TER119), CD3 (145-2C11), CD19 (6D5), c-Kit (2B8), FLT3 (A2F10), CD150 (TC15-12F12.2), MHC-II (AF6-120.1), F4/80 (BM8), CD45.2 (104), CD29 (HMß1-1), CD51 (RMV-7), CD54 (YN1/1.7.4), CD31 (390), gp38 (8.1.1), CD105 (MJ7/18), Thy1.2 (30H12), VCAM1 (429), CD140a (APA5), CD146 (ME-9F1), Sca-1 (D7), ER-TR7 (Sc-73355), MAdCAM1 (MECA-367). Conjugates included streptavidin-Alexa780, streptavidin-APCCy7, streptavidin-PE, and streptavidin-FITC. Antibodies and conjugates were purchased from Biolegend (San Diego, CA, United States) or eBiosciences (Parkville, Victoria, Australia). Fluorescence minus one (FMO) controls or isotype controls were used to set gates to delineate specific antibody binding. Discrimination of dead cells was carried out following staining with $1 \mu \mathrm{g} / \mathrm{ml}$ propidium iodide (PI). Flow cytometric analysis and sorting utilized either a FACSDiva or a LSRII flow cytometer (Becton Dickinson: Franklin Lakes, NJ, United States). Postacquisition analysis was carried out using FlowJo software (Tree Star: Ashland, OR, United States). For isolation of stromal subsets, cells were sorted into FACS buffer without added sodium 
azide, washed twice with phosphate buffered saline (SigmaAldrich), and plated for in vitro growth analysis. Sorted cells were re-analyzed flow cytometrically to ensure that purity of the sort was $>99 \%$. For sorting HSC, $\mathrm{Lin}^{-}$bone marrow progenitors were prepared and stained with fluorochromeconjugated antibodies to lineage markers, as well as specific markers. The longterm (LT)-HSC subset was isolated as $\mathrm{Lin}^{-} \mathrm{Sca}-$ $1^{+} \mathrm{c}-\mathrm{Kit}^{+}$Flt3 ${ }^{-} \mathrm{CD} 150^{+}$cells (Kiel et al., 2005).

\section{Culture of Stromal Fractions}

Stromal cells sorted by flow cytometry were cultured $\left(5 \% \mathrm{CO}_{2}\right.$ in air with $95 \%$ humidity at $37^{\circ} \mathrm{C}$ ) in a 6-well plate containing sDMEM for 28 days or until about $90 \%$ confluent. Cells were passaged from 6-well plates into a $25 \mathrm{~cm}^{2}$ flask and maintained until $90 \%$ confluency was obtained. Cells underwent a second passage from $25 \mathrm{~cm}^{2}$ into $75 \mathrm{~cm}^{2}$ flasks. Cells in the $75 \mathrm{~cm}^{2}$ flasks were either analyzed for cell surface marker expression using flow cytometry, or tested for hematopoietic support capacity in co-culture assays.

\section{Stromal Co-cultures}

In order to assess hematopoietic support capacity of stroma, $\mathrm{Lin}^{-}$ bone marrow cells were prepared as above and overlaid at 1$5 \times 10^{4}$ cells $/ \mathrm{ml}$ in $20 \mathrm{ml}$ sDMEM above stromal monolayers of 80-90\% confluency. In some experiments, HSC were overlaid at $1-5 \times 10^{2}$ cells $/ \mathrm{ml}$ in $5 \mathrm{ml}$ sDMEM above stroma. Co-cultures were kept at $37^{\circ} \mathrm{C}, 5 \% \mathrm{CO}_{2}$ in air and $97 \%$ humidity. Production of cells in co-cultures was monitored over a period of 4-6 weeks using flow cytometry and light microscopy. Since co-cultures established at different times varied in cell yield over the course of culture, each test of hematopoietic support capacity included $5 \mathrm{G} 3$ stroma as a control. At 7-day intervals, non-adherent cells were collected by aspiration and replacement of medium. Trypan blue exclusion was used to determine cell yield. Cells were then resuspended in FACS buffer for flow cytometry, in order to detect cell surface marker expression and to define and quantitate subsets.

\section{Gene Expression Analysis}

Gene expression was measured by quantitative real time polymerase chain reaction (qRT-PCR). Total RNA was isolated from stromal cell lines using the RNeasy mini kit and the manufacturer's protocol (Qiagen, SABiosciences: Valencia, CA, United States). Genomic DNA elimination mix was added to 400-600 $\mu \mathrm{g}$ of RNA followed by incubation for $5 \mathrm{~min}$ at $42^{\circ} \mathrm{C}$ to purify RNA. Following this, Buffer BC3, Control P2, Reverse Transcriptase mix and RNase-free water were added in ratios of $4: 1: 2: 3$ for preparation of cDNA. Denaturation proceeded for $15 \mathrm{~min}$ at $42^{\circ} \mathrm{C}$, then for $5 \mathrm{~min}$ at $95^{\circ} \mathrm{C}$ to convert RNA into cDNA. Equal volumes of $\mathrm{cDNA}$ and primer were mixed. Primers were purchased from SABioscience (Frederick, MD, United States: Scf: PPM02983C; Cxcl12: PPM02965E; Actb: PPM02945A). The cDNA/primer mix was then added to the $\mathrm{RT}^{2}$ SYBR Green Mastermix and RNase-free water in a ratio of 1:6.25:5.25, respectively. Samples were loaded on to a LightCycler 480 (Roche: Penzberg, BAV, Germany) with cycling conditions: 1 cycle for $10 \mathrm{~min}$ at $95^{\circ} \mathrm{C}$ to activate DNA Taq Polymerase, followed by 45 cycles of $15 \mathrm{~s}$ at $95^{\circ} \mathrm{C}$ for extension, and then $1 \mathrm{~min}$ at $60^{\circ} \mathrm{C}$ for fluorescence data collection. Roche LightCycler 480 software v.11.2.9.11 was used to analyze qRTPCR data. Derivation of crossing point $\left(C_{\mathrm{p}}\right)$ was carried out using the absolute quantification (2nd derivative max) method at high confidence. $C_{p}$ is defined as the point at which the maximal increase in fluorescence occurs within the log-linear phase. The $C_{\mathrm{p}}$ value is also referred to as threshold cycle $\left(C_{\mathrm{t}}\right) . \Delta C_{\mathrm{t}}=C_{\mathrm{t}}\left(G_{i}\right)-C_{\mathrm{t}}\left(G_{\mathrm{r}}\right)$, where $G_{i}$ refers to gene of interest and $G_{\mathrm{r}}$ refers to reference gene. Fold change relative to $\beta$-actin was expressed as $2^{-\Delta \mathrm{Ct}}$ (gene of interest) $/ 2^{-\Delta \mathrm{Ct}}$ $(\beta$-actin).

\section{Microscopy}

Cell morphology was observed and photographed using an EVOS $^{\circledR}$ FL digital fluorescence microscope (Electron Microscope Sciences: Hatfield, PA, United States), equipped with a Sony ${ }^{\circledR}$ ICX445 CCD camera (Sony: Minato, TKY, JP).

\section{Statistical Analysis}

Data are presented as mean \pm standard error (SE) for sample size $n$. The Student's $t$-test was used to assess significance $(p \leq 0.05)$.

\section{RESULTS}

\section{Composition of Splenic Stroma}

In order to investigate the stromal cell composition of murine spleens, collagenase-dissociated stromal cells were fractionated using flow cytometry to enrich or deplete subsets expressing a particular marker(s). Previously 6 day old spleens were found to give optimal production of longterm stroma-dependent cultures supporting hematopoiesis, although other ages could be used but with less effectiveness. For this reason, 6 day old mice were used for characterization of splenic stromal subsets. The initial choice of markers was based on the phenotype of the

TABLE 1 | Proportion of cells in CD45- ${ }^{-}$stromal fractions.

\begin{tabular}{lr}
\hline Spleen fraction $^{\mathbf{a}}$ & \multicolumn{1}{c}{$\%$ cells $^{\mathbf{b}}$} \\
\hline $\mathrm{CD}^{+} 9^{+}$ & $91.70 \pm 2.70$ \\
$\mathrm{Sca}^{+}{ }^{+}$ & $1.57 \pm 0.50$ \\
$\mathrm{CD}^{+} 1^{+}$ & $1.02 \pm 0.23$ \\
gp38 $^{+}$ & $0.99 \pm 0.32$ \\
$\mathrm{CD}^{+} 05^{+}$ & $13.07 \pm 1.26$ \\
$\mathrm{CD}^{+} 40 a^{+}$ & $1.76 \pm 0.67$ \\
CD51 $^{+}$ & $1.64 \pm 0.73$ \\
ER-TR7 $^{+}$ & $2.12 \pm 0.67$ \\
Thy1.2 $^{+}$ & $0.32 \pm 0.11$ \\
CD146 $^{+}$ & $1.33 \pm 0.36$ \\
MAdCAM1 $^{+}$ & $0.35 \pm 0.06$ \\
VCAM1 $^{+}$ & $6.82 \pm 3.60$
\end{tabular}

aStromal cells were isolated from neonatal murine spleen using collagenase treatment. Cells were labeled with fluorochrome-conjugated antibodies and flow cytometry used to separate marker-positive and marker-negative fractions for quantification. ${ }^{b}$ Data represent mean $\pm S E(n=3)$. 
TABLE 2 | Phenotype of stromal fractions after culture.

\begin{tabular}{|c|c|c|c|c|c|c|c|c|}
\hline \multirow[t]{2}{*}{ Cell fractions $^{a, b}$} & \multirow[t]{2}{*}{ Growth $^{\mathrm{c}}$} & \multicolumn{7}{|c|}{ Phenotype of 28 day stroma ${ }^{d}$} \\
\hline & & Sca1 & gp38 & CD51 & CD105 & ERTR7 & CD140a & Thy1.2 \\
\hline \multicolumn{9}{|c|}{ Endothelial cell markers } \\
\hline $\mathrm{CD} 1^{+}(n=1)$ & - & & & & & & & \\
\hline $\mathrm{CD} 1^{-}(n=1)$ & $* *$ & ++ & + & +++ & - & - & + & + \\
\hline $\operatorname{VCAM}^{+}(n=1)$ & - & & & & & & & \\
\hline $\operatorname{VCAM}^{-}(n=1)$ & $*$ & +++ & +++ & +++ & +++ & - & - & +++ \\
\hline \multicolumn{9}{|l|}{ PVRC markers } \\
\hline $\mathrm{CD}_{146}^{+}(n=4)$ & - & & & & & & & \\
\hline $\mathrm{CD}^{146}{ }^{-}(n=4)$ & - & & & & & & & \\
\hline $\mathrm{MadCAM}^{+}(n=3)$ & - & & & & & & & \\
\hline MAdCAM1- $(n=3)$ & - & & & & & & & \\
\hline \multicolumn{9}{|c|}{ Common stromal markers } \\
\hline Sca- ${ }^{+}(n=3)$ & $*$ & +++ & ++ & +++ & + & - & - & +++ \\
\hline Sca-1- $(n=3)$ & $*$ & +++ & ++ & +++ & + & - & - & ++ \\
\hline $\mathrm{CD}_{51}+(n=1)$ & $*$ & +++ & +++ & +++ & + & - & + & +++ \\
\hline $\mathrm{CD} 51^{-}(n=1)$ & $*$ & +++ & +++ & +++ & ++ & - & - & +++ \\
\hline $\mathrm{ER}^{-\mathrm{TR}^{+}}(n=2)$ & $*$ & +++ & ++ & +++ & - & - & - & +++ \\
\hline ER-TR7- $(n=2)$ & $*$ & +++ & +++ & ++ & +++ & - & - & - \\
\hline
\end{tabular}

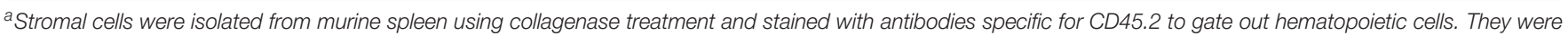

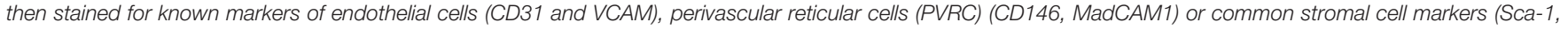

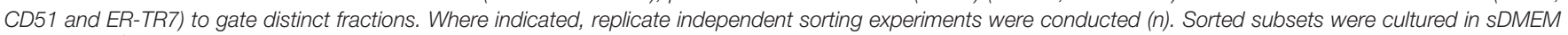

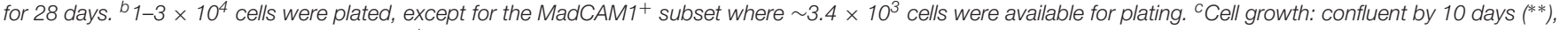

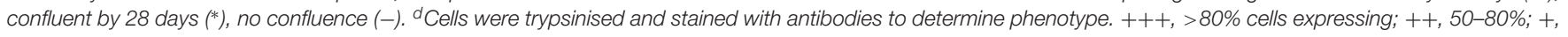
10-50\%; - , <10\%.

TABLE 3 | Further phenotyping of stromal fractions after culture.

\begin{tabular}{|c|c|c|c|c|c|c|c|c|}
\hline \multirow[t]{2}{*}{ Cell fractions ${ }^{a, b}$} & \multirow[t]{2}{*}{ Growth ${ }^{c}$} & \multicolumn{7}{|c|}{ Phenotype of 28 day stroma } \\
\hline & & Sca1 & gp38 & CD51 & CD105 & ERTR7 & CD140a & Thy1.2 \\
\hline $\mathrm{CD}^{2} 9^{+}(n=2)$ & $* *$ & +++ & +++ & +++ & +++ & - & + & +++ \\
\hline $\mathrm{CD}^{2} 9^{-}(n=2)$ & $x$ & & & & & & & \\
\hline${\mathrm{gp} 38^{+}}(n=5)$ & $*$ & +++ & +++ & ++ & ++ & - & ++ & ++ \\
\hline${\mathrm{gp} 38^{-}}^{-}(n=5)$ & - & & & & & & & \\
\hline $\mathrm{CD}_{105^{+}}(n=5)$ & $*$ & +++ & +++ & ++ & +++ & - & + & ++ \\
\hline $\mathrm{CD}^{105^{-}}(n=5)$ & - & & & & & & & \\
\hline${\mathrm{CD} 140 \mathrm{a}^{+}}(n=5)$ & $*$ & ++ & +++ & ++ & - & - & - & ++ \\
\hline $\mathrm{CD}^{140 \mathrm{a}^{-}}(n=5)$ & - & & & & & & & \\
\hline Thy $1.2^{+}(n=3)$ & $*$ & ++ & + & + & + & - & ++ & +++ \\
\hline Thy $1.2^{-}(n=3)$ & $x$ & & & & & & & \\
\hline
\end{tabular}

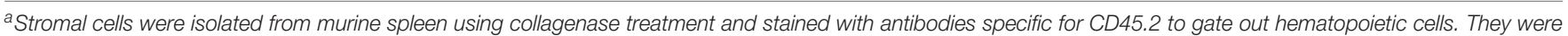

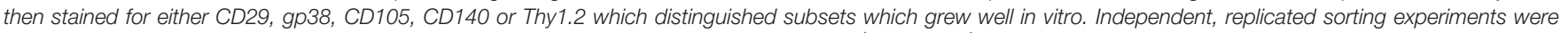

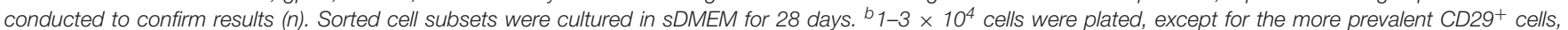

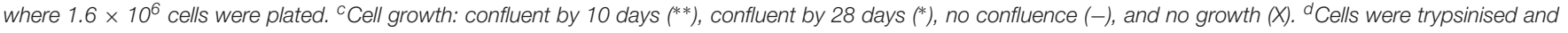
stained with antibodies to determine phenotype.,$+++>80 \%$ cells expressing;,$++ 50-80 \% ;+, 10-50 \% ;-,<10 \%$.

5G3 line, as well as knowledge of mesenchymal cells. A high proportion of splenic stromal cells $(91.70 \pm 4.05 \%)$ was found to express CD29 (integrin beta-1) (Table 1). In contrast, markers like Sca-1, CD31, gp38, CD140a, CD51, ER-TR7, Thy1.2, CD146, MadCAM1 and VCAM1 were expressed by minority populations of stroma (1-3\%) (Table 1). CD105+ cells represented $\sim 13 \%$ of stromal cells in spleen, with VCAM1 ${ }^{+} \sim 7 \%$. Splenic stromal cell characterization was therefore challenging, requiring analysis and isolation of rare stromal cells expressing markers of interest.

In developing a strategy for detection of stromal subsets which support hematopoiesis, we were cognizant of the fact that the $5 \mathrm{G} 3$ phenotype may not accurately reflect the stromal cell from which 5G3 derived. We therefore performed a systematic study 
of marker defined stromal fractions to eliminate subsets which did not grow, and which did not support hematopoiesis. An important criterion was the capacity of the stromal fraction to grow to confluency within 28 days in order to test hematopoietic support capacity. This approach precluded multicolor sorting yielding very small numbers of cells which could not form a monolayer in vitro.

In a first experiment, marker identity of fractions which grew in vitro was determined by comparing growth capacity of subsets enriched or depleted of cells expressing a given marker. Markers were considered unimportant when the same growth capacity was achieved for depleted and enriched fractions (either did or did not grow), and where depletion and not enrichment gave a growing population. Depletion of stroma expressing the endothelial markers CD31 and VCAM1 gave a stromal population which grew readily, so these markers were removed from consideration (Table 2). Stromal cells enriched or depleted for CD146 and MadCAM, known markers of niche elements in bone marrow, did not grow despite multiple replicated experiments (Table 2). This could be due to inability to isolate enough cells, or their inherent inability to form a monolayer, so these markers were eliminated from further consideration. The more common stromal cell markers Sca-1, CD51 and ERTR7, were not deterministic of growth since both depleted and enriched subsets grew (Table 2). This initial screen led to the identification of CD29, gp38, CD105, CD140a and Thy1 as deterministic markers. Only fractions enriched for, but not depleted of CD29, gp38, CD105, Thy1.2 and CD140a, could reach confluent growth by 28 days (Table 3 ). These mesenchymal markers would appear to identify stromal cells that can replicate in culture. Subsets expressing these markers were therefore tested for hematopoietic support capacity.

Cells which grew out of 28-day cultures were also mesenchymal in terms of phenotype (Tables 2, 3). For all stromal fractions tested, cells which grew expressed Sca-1 (50-80\% of cells), with a majority of cells also expressing gp 38 , CD51 and Thy1.2 (50-80\%). The expression of CD105 was variable, with some cultures showing no expression. CD140a
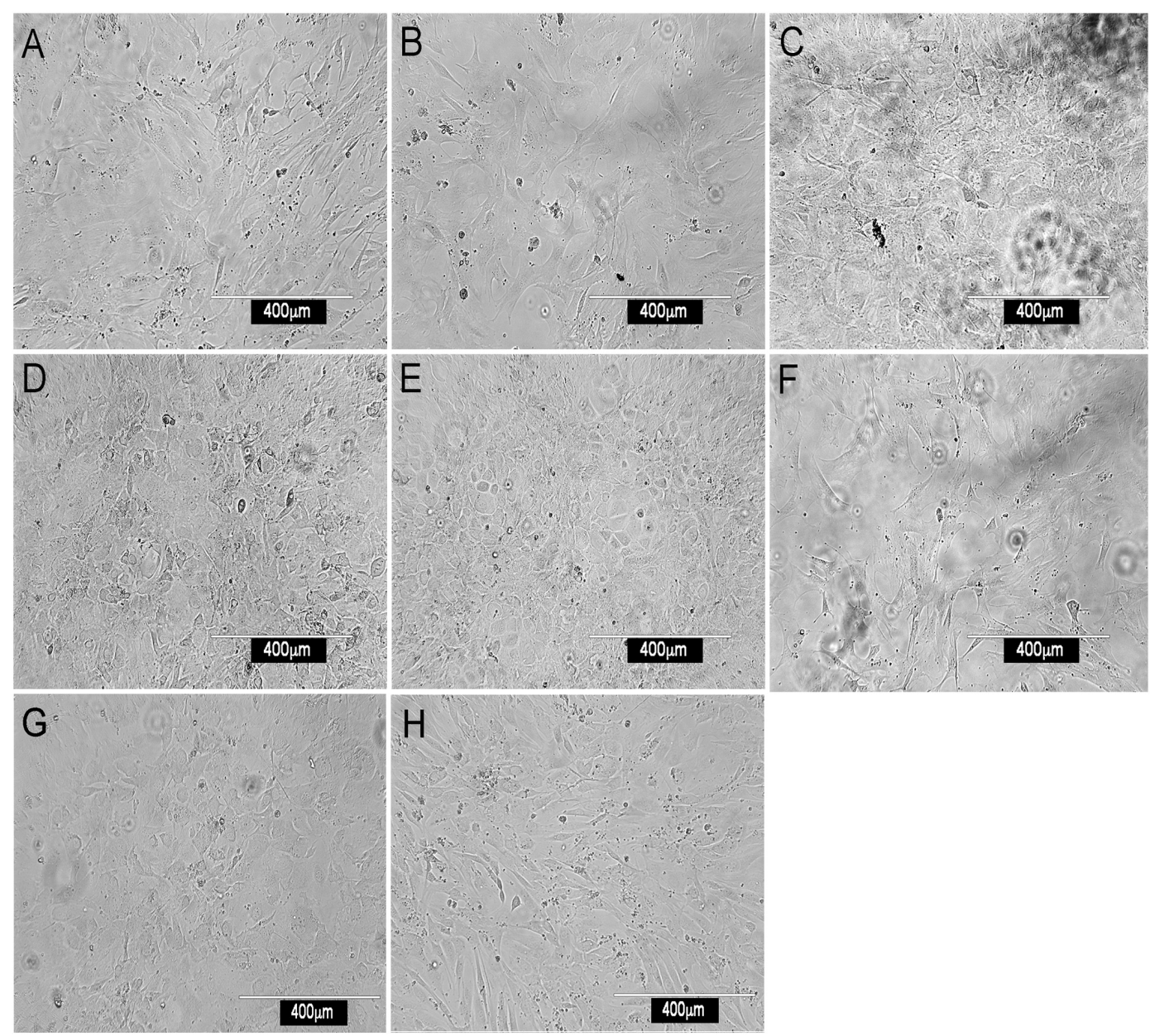

FIGURE 1 | Morphology of splenic stromal fractions. Stromal cells were isolated from murine spleen using collagenase treatment, stained with antibody and sorted flow cytometrically. Cells were cultured and photographed after 28 days using a camera attached to an inverted phase microscope. Stromal fractions sorted on the

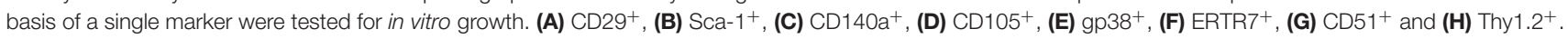


expression was also weak and variable with between 0 and $50 \%$ of cells expressing this marker. None of the cultures showed expression of the fibroblastic marker ER-TR7. These data need to be interpreted with caution since in vitro growth can moderate or enhance expression of markers. In sum, a small number of lines of distinct mesenchymal type can be cultured, showing variability in expression of CD105 and CD140a.

\section{Microscopic Examination of Cultured Stromal Fractions}

Most stromal monolayers were heterogeneous showing a mix of spindle-shaped fibroblastic and cuboidal cells. The extent of confluency achieved for different fractions varied even after 28 days of culture. Enrichment of $\mathrm{CD}_{29}{ }^{+}, \mathrm{Sca}^{+}, \mathrm{CD} 140 \mathrm{a}^{+}$,

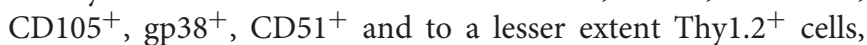
gave confluent, extensive monolayers comprising mainly spindleshaped cells, reflective of mesenchymal stroma (Figure 1). Enrichment for $\mathrm{CD}^{2} 9^{+}$cells gave a very mixed population of cuboidal and spindle-shaped cells, consistent with CD29 as a marker of $\sim 90 \%$ of stromal cells in spleen (Table 1). The extensive heterogeneity within the $\mathrm{CD} 29^{+}$fraction was revealed by culturing CD29-expressing cells as three independent subcultures (A, B, and C) for 28 days. Stromal cells in each of $A, B$, and $C$ subcultures showed very different growth rates and morphologies. Sub-culture A reflected spindle-shaped cells, subculture B sparse cuboidal cells, and sub-culture $\mathrm{C}$ was a confluent mixture of cell types (data not shown). The ER-TR7 ${ }^{+}$fibroblastic population grew rapidly yielding fibroblastic cells (Figure 1).

\section{Further Marker Characterization of Stroma}

Since $\mathrm{CD}^{2} 9^{+}$cells represented $\sim 90 \%$ of stroma, subfractions were isolated on the basis of CD105, Sca-1 and gp38 expression, and compared for growth. In general, stromal fractions that expressed either CD29 or gp38 grew well (Supplementary Table S1). Again, the phenotype of stromal cells which grew out of 28 days cultures was consistently Sca- $1^{+}$gp $38^{+}$Thy $1.2^{+} \mathrm{CD} 29^{+} \mathrm{CD} 51^{+}$, with variability in the expression of CD105 and CD140a (Supplementary Table S1).

As a prelude to assessment of potential of subsets to support hematopoiesis, qRT-PCR was used to measure expression of Scf and Cxcl12 (Figure 2) which encode factors known to regulate hematopoiesis in bone marrow (Sugiyama et al., 2006). Recent work on spleen stroma has aligned Cxcl12 expression with perivascular reticular cells, and $S c f$ expression with both endothelial and perivascular reticular cells in the red pulp of murine spleen (Inra et al., 2015). The A, B, and C subcultures derived from an isolate of $\mathrm{CD}_{2} 9^{+}$stromal cells were compared with $5 \mathrm{G} 3$ stroma and with several sorted fractions of $\mathrm{CD} 105^{+}$, $\mathrm{CD} 29^{+} \mathrm{gp} 38^{+} \mathrm{Sca}-1^{-}$and $\mathrm{CD} 29^{+} \mathrm{gp} 38^{+} \mathrm{Sca}-1^{+}$spleen stroma, to measure gene expression relative to $\beta$-actin (Figure 2). Cxcl12 was highly expressed in all stroma, and each not significantly different from 5G3 at $p=0.05$. Scf was more weakly expressed, not detectable in 3 subsets, and each not significantly different from 5G3 at $p=0.05$ level. The dominant expression of Cxcl12 and weak expression of $S c f$ by stromal fractions is consistent with

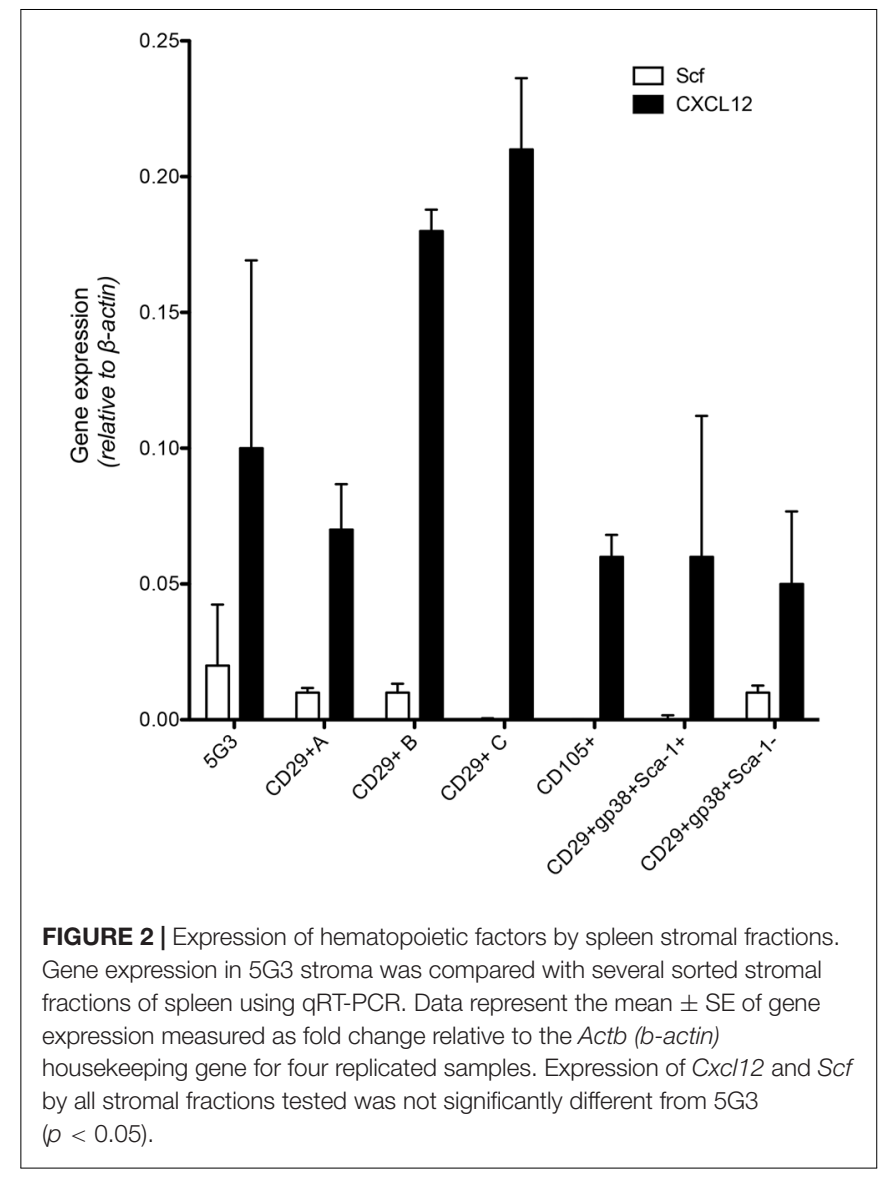

perivascular reticular cells amongst the spleen stromal fractions (Inra et al., 2015).

An explanation for the data achieved to date is that one or a small number of stromal subsets exist in spleen which are readily cultured in vitro. These are identifiable as a CD29+ ${ }^{+}$ca$1^{+} \mathrm{Thy}^{+}{ }^{+} \mathrm{CD} 51^{+} \mathrm{gp} 38^{+}$population, and contain perivascular reticular cells.

\section{Assessment of Hematopoietic Support Capacity of Stromal Fractions}

To assess hematopoietic support capacity of stromal fractions, confluent monolayers were grown for 28 days and used to establish co-cultures by overlay of $\mathrm{Lin}^{-}$bone marrow cells from CD45-allotype distinct mice. The production of progenitors, myeloid cells and dendritic cells was measured at 21 days through staining with a range of antibodies. The CD11b-CD11 $\mathrm{c}^{-}$subset was identified as 'progenitors' although this phenotype describes a heterogeneous population of progenitors/precursors. Myeloid cells were identified as CD11b ${ }^{+} \mathrm{CD} 11 \mathrm{c}^{-} \mathrm{F} 4 / 80^{-} \mathrm{MHC}^{-I^{-}}{ }^{-}$, L-DC

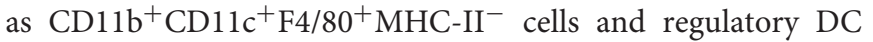

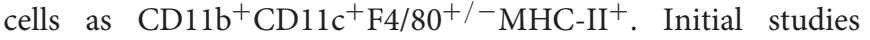
involved stromal cell fractions separated by a single marker. Eleven independent co-culture experiments were performed to test various stromal fractions using $5 \mathrm{G} 3$ as a control. Nine representative experiments show \% yield of cells relative 

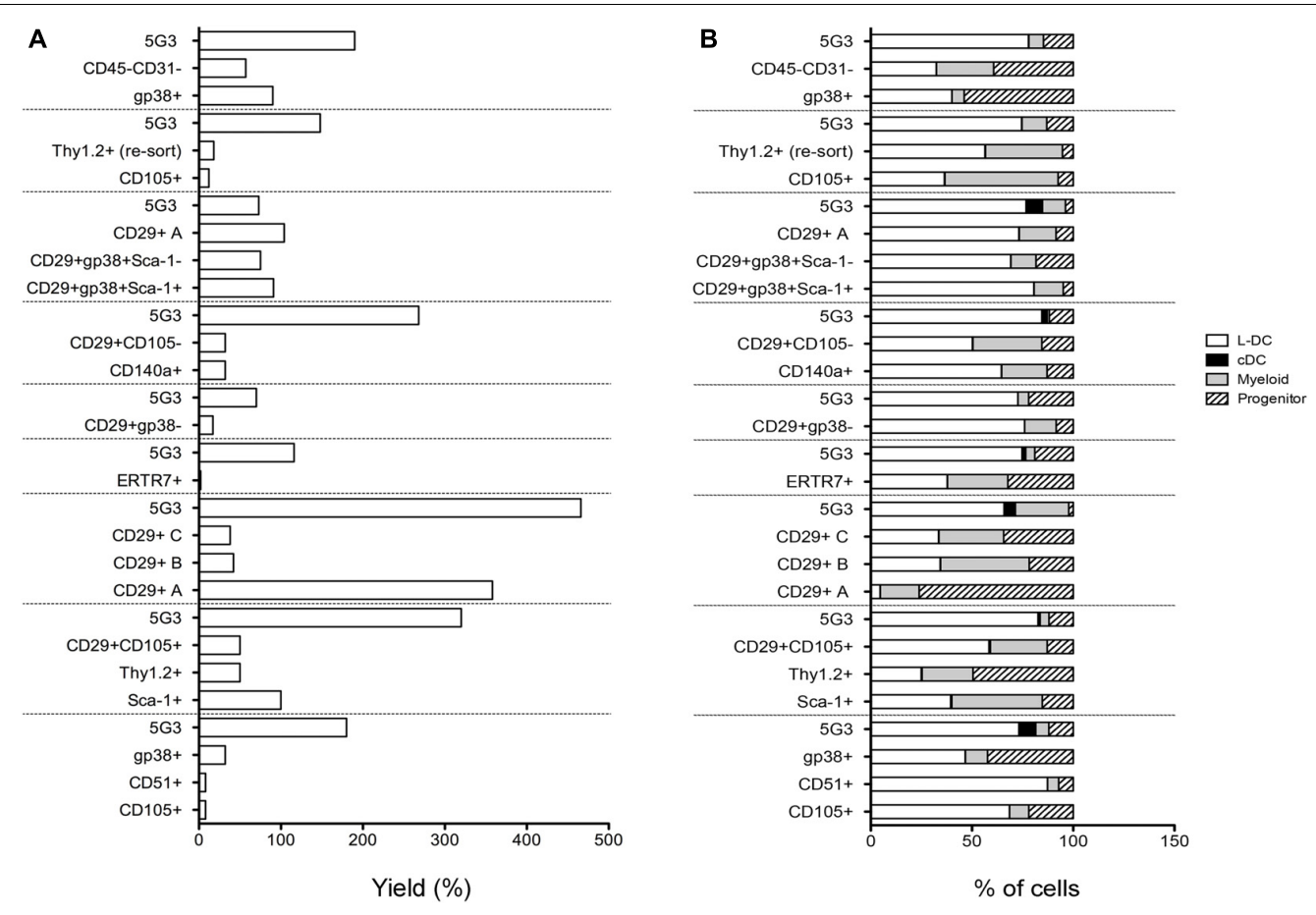

FIGURE 3 | In vitro hematopoietic support capacity of stromal cell fractions. Stromal fractions were isolated from collagenase treated spleen stroma, sorted on the basis of marker expression and cultured for 28 days until confluent. Lin ${ }^{-}$bone marrow cells was then overlaid above stroma at $1-5 \times 10^{4} \mathrm{cells} / \mathrm{ml}$ in $20 \mathrm{ml}$. Non-adherent cells were collected after 21 days and stained with antibodies to CD11b, CD11c, MHC-II and F4/80 to delineate myeloid/dendritic cell production. Flow cytometric analysis was used to identify subsets of progenitors (CD11 $\left.\mathrm{b}^{-} \mathrm{CD} 11 \mathrm{c}^{-}\right)$, myeloid cells $\left(\mathrm{CD} 11 \mathrm{~b}^{+} \mathrm{CD} 11 \mathrm{c}^{-} \mathrm{F} 4 / 80^{-} \mathrm{MHC}-\|^{-}\right), \mathrm{L}^{-} \mathrm{DC}$ $\left(\mathrm{CD} 11 \mathrm{~b}^{+} \mathrm{CD} 11 \mathrm{C}^{+} \mathrm{F} 4 / 80^{+} \mathrm{MHC}^{-} \|^{-}\right)$, and $\mathrm{CDC}$-like cells $\left(\mathrm{CD} 11 \mathrm{~b}^{+/-} \mathrm{CD} 11 \mathrm{C}^{+} \mathrm{F} 4 / 80^{-} \mathrm{MHC}^{-} \|^{+}\right)$. Multiple individual self-controlled experiments were conducted, each comparing cell production by different fractions in comparison with 5G3. Data is shown for each of 9 experiments as: (A) \% yield as number of cells produced relative to input cell number, and (B) proportional representation of subsets.

to input cell number (Figure $\mathbf{3 A}$ ). An example of the flow cytometric gates used to identify cell subsets produced in co-cultures is shown in Figure $\mathbf{4 B}$ and has also been published previously (Lim et al., 2018). Most stromal fractions were low cell producers compared with 5G3, including $\mathrm{CD} 105^{+}, \mathrm{CD} 1^{+}$, gp $38^{+}, \mathrm{Sca}-1^{+}$, Thy $1.2^{+}, \mathrm{CD} 29^{+} \mathrm{CD} 105^{+}$, $\mathrm{CD} 29^{+} \mathrm{B}$ and $\mathrm{CD} 29^{+} \mathrm{C}, \mathrm{ERTR}^{+}, \mathrm{CD} 29^{+} \mathrm{gp} 38^{-}, \mathrm{CD} 140 \mathrm{a}^{+}$, $\mathrm{CD} 29^{+} \mathrm{CD} 105^{-}$and $\mathrm{CD} 45^{-} \mathrm{CD} 31^{-}$stroma. Several stroma gave yields equal to $5 \mathrm{G} 3$ including $\mathrm{CD} 29^{+} \mathrm{A}, \mathrm{CD} 29^{+}$gp $38^{+} \mathrm{Sca}-1^{+}$and $\mathrm{CD} 29^{+} \mathrm{gp} 38^{+} \mathrm{Sca}-1^{-}$. Co-cultures established using the $\mathrm{CD} 29^{+}$ subcultures A, B, and C, exhibited different hematopoietic support capacity, again reflective of the heterogeneity within this stromal fraction (Figure 3A). Replication experiments therefore involved independent sorts and growth of stromal fractions for 4 weeks. For reasons of low subset size it was not possible to perform replicate tests of hematopoiesis for any one sorted stromal fraction. Since the independently sorted and grown populations reflect distinct outgrowths of a heterogeneous population as seen for subcultures of the $\mathrm{CD} 29^{+}$fraction, it is not possible to determine with certainty a measure of the hematopoietic support capacity for impure stromal fractions. It was anticipated, however, that if a stromal fraction could be defined on the basis of multiple markers that it would be more likely to reflect a single stromal cell population.
The phenotype of cells produced in co-cultures was found to be similar across many stromal subsets analyzed across 11 different experiments (Figure 3B). Furthermore, after 21 days, there was a predominance of L-DC produced in most co-cultures with variable representation of myeloid cells and progenitors. Only $5 \mathrm{G} 3$ co-cultures showed evidence of a small subset of regulatory DC which are known to be transiently produced (Periasamy et al., 2013). Initial experiments confirmed no production of $\mathrm{T}$ or $\mathrm{B}$ lymphoid cells in any co-culture established with spleen stroma or the $5 \mathrm{G} 3$ cell line, consistent with previous reports (Periasamy et al., 2009; Petvises and O'Neill, 2014b), and also with early studies on longterm stromal cultures of spleen (O'Neill et al., 2004, 2014). Some stromal co-cultures showed more extreme changes in cell production, most notably subculture $\mathrm{CD} 29^{+} \mathrm{A}$ which produced a high number of cells with a predominant population of progenitors (Figure 3B).

Relative to the input number of $\mathrm{Lin}^{-}$bone marrow progenitors, $5 \mathrm{G} 3$ co-cultures yielded a $2.034 \pm 0.350$ (mean $\pm \mathrm{SE}$ ) $(n=9)$ increase in cell number after 21 days (Figure 3A). This fold change increase is more significant due to the fact that it represents cell production measured at 21 days, and does not take into account cells produced and lost at biweekly medium change. The question of whether stromal co-cultures cause expansion or maintenance of HSPC can be addressed as well. Nineteen of 20 co-cultures shown across 9 experiments in Figure $\mathbf{3}$ gave a yield 


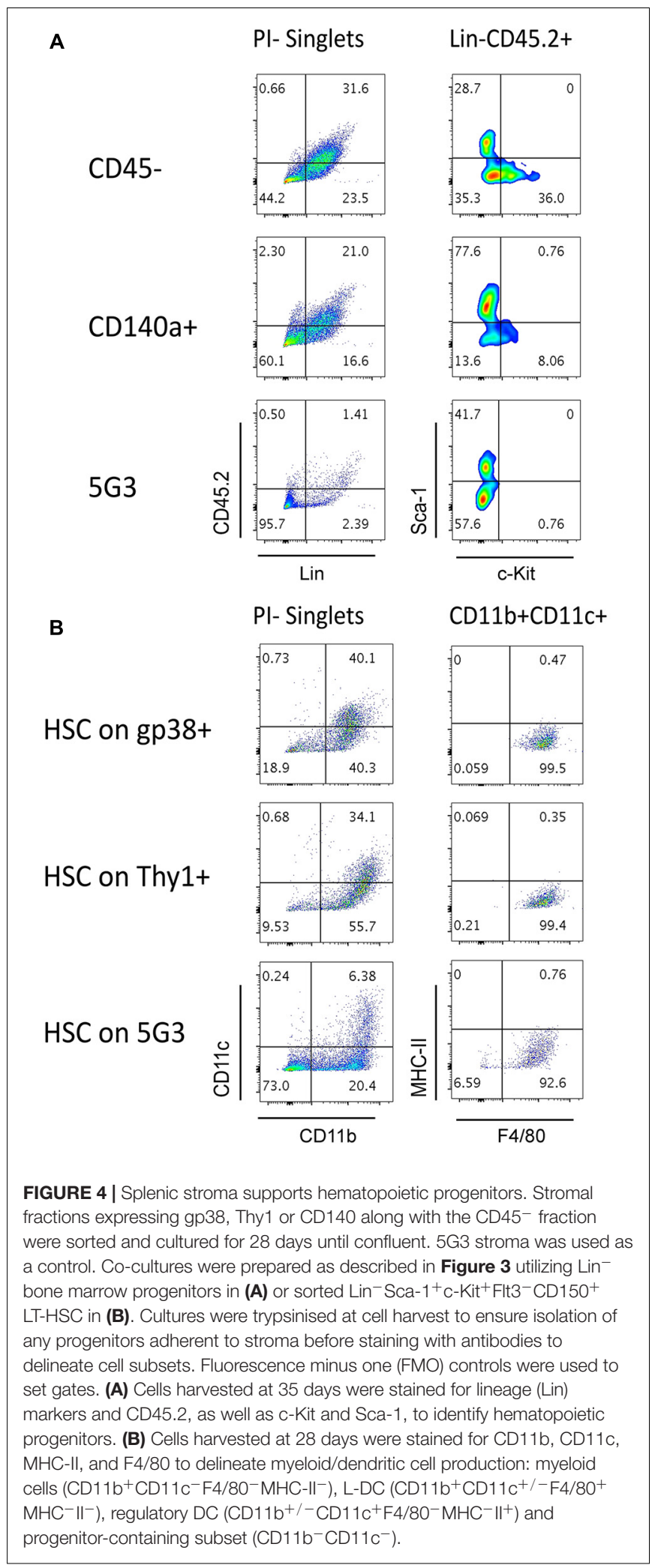

of progenitors which was less than the input number of $\mathrm{Lin}^{-}$ bone marrow progenitors. However, $\mathrm{CD} 29^{+}$A cultures gave a 2.7-fold increase in progenitors collected after 21 days compared with input cell number (Figure 3B). This initial study confirmed that spleen contains subsets of $\mathrm{CD}_{2}{ }^{+}$cells which can support the expansion of HSPC cells. Despite the low overall yield of cells, gp $38^{+}$stromal co-cultures appear to maintain a higher proportion of progenitors.

\section{Stromal Cell Capacity to Maintain Hematopoietic Progenitors}

The question of whether stromal co-cultures can maintain and expand hematopoietic stem and progenitor cells (HSPC) in vitro has clinical importance. We therefore attempted to identify HSC in several co-cultures established with freshly prepared splenic stroma. Non-adherent cells collected from co-cultures were stained to detect $\mathrm{Lin}^{-} \mathrm{CD} 45.2^{+} \mathrm{Sca}-1^{+} \mathrm{c}-\mathrm{Kit}^{+}$ HSPC. Only $\mathrm{Lin}^{-} \mathrm{CD} 45.2^{+} \mathrm{c}^{-\mathrm{Kit}^{+}}$cells could be detected in cocultures established above the $\mathrm{CD}^{-} 5^{-}$and $\mathrm{CD} 140 \mathrm{a}^{+}$spleen stroma fractions tested, and none in $5 \mathrm{G} 3$ co-cultures (Figure 4A). These cells could reflect previously described common myeloid progenitors (Akashi et al., 2000), myeloid/dendritic progenitors (Fogg et al., 2006) or common dendritic progenitors (Liu et al., 2009). Previously we reported that HSPC appear to be tightly adhered to stroma so their isolation may not be easily achieved (Wilson et al., 2000). It is also possible that HSC may be present, but after for 3-4 weeks of culture, attain a different phenotype. In particular, culturing of $\mathrm{Lin}^{-} \mathrm{Sca}-1^{+} \mathrm{c}-\mathrm{Kit}^{+}$cells over stroma may lead to loss of the Sca-1 marker, a phenomenon reported previously for mesenchymal stem cells in vitro (Deng et al., 2015). Previously we reported evidence for maintenance of low numbers of HSPC in spleen longterm stromal cultures through ability to induce hematopoietic reconstitution in irradiated host mice (O’Neill et al., 2014).

We showed previously that the 5G3 stromal cell line can maintain bone marrow-derived HSC and MPP and support hematopoiesis to give a mixed population of L-DC and progenitors (Petvises and O'Neill, 2014b). Here we tested the capacity of several ex vivo spleen stromal fractions to support hematopoiesis in overlaid $\mathrm{Lin}^{-} \mathrm{Sca}-1^{+} \mathrm{c}-\mathrm{Kit}^{+} \mathrm{Flt}^{-}{ }^{-} \mathrm{CD} 150^{+}$HSC. When non-adherent cells were collected and stained for marker expression, a substantial population of $\mathrm{CD} 11 \mathrm{~b}^{+} \mathrm{CD} 11 \mathrm{c}^{+}$cells was detected for each of the gp $38^{+}$and $\mathrm{Thy}^{+}$stromal fractions as well as for 5G3 (Figure 4B). These cells were further shown to express F4/80 but not MHC-II consistent with production of L-DC. A substantial CD11b-CD11 ${ }^{-}$subset was detectable particularly for $5 \mathrm{G} 3$ cocultures $(73 \%)$ while lower numbers of progenitors were present in co-cultures of gp38 $8^{+}(18.9 \%)$ and Thy $^{+}(9.53 \%)$ stroma (Figure $4 \mathbf{B}$ ). This subset is expected to contain hematopoietic progenitors.

\section{Fine Definition of Stromal Subsets in Spleen}

Further experiments were therefore aimed at identification of subsets of more defined phenotype and hematopoietic support capacity. Splenic stroma was characterized using five cell surface markers to delineate subsets amongst the total ex vivo population. The panel of markers comprised Thy1.2, Sca-1, CD105, CD51, and CD140a, informed by the 5G3 phenotype and data obtained 


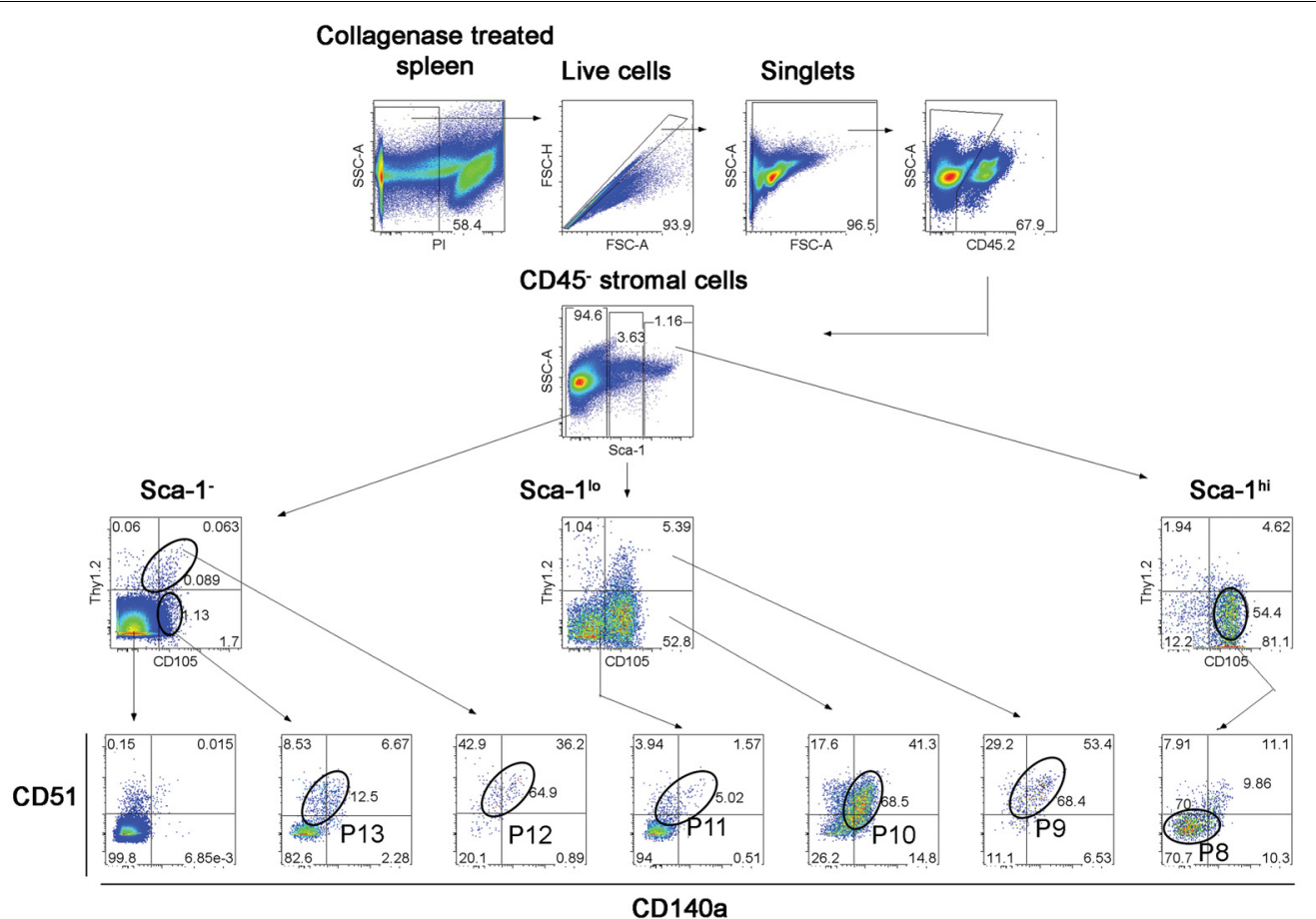

FIGURE 5 | Flow cytometric analysis of stromal subsets in spleen. Stromal cells were isolated from murine spleen using collagenase treatment and stained with antibodies specific for CD45.2, Sca-1, Thy1.2, CD105, CD51 and CD140a. Prior to flow cytometry, cells were incubated with propidium iodide for gating live (PI-) cells using PI versus SSC analysis. Singlets were then selected on the basis of FSC-H and FSC-A staining. Cells were then gated on FSC to eliminate red blood cells. Multicolor analysis was then used to detect subsets amongst the CD45.2- population of non-hematopoietic stromal cells. Fluorescence minus one (FMO) controls were used to set gates. Numbers in quadrants, or on circle gates, represent \% specific binding. Distinct subsets were identified as P8, P9, P10, P11, P12, and P13. Data reflect 3 independent experiments.

TABLE 4 | Characterization of specific subsets amongst the spleen stromal fraction.

(A) Subset representation.

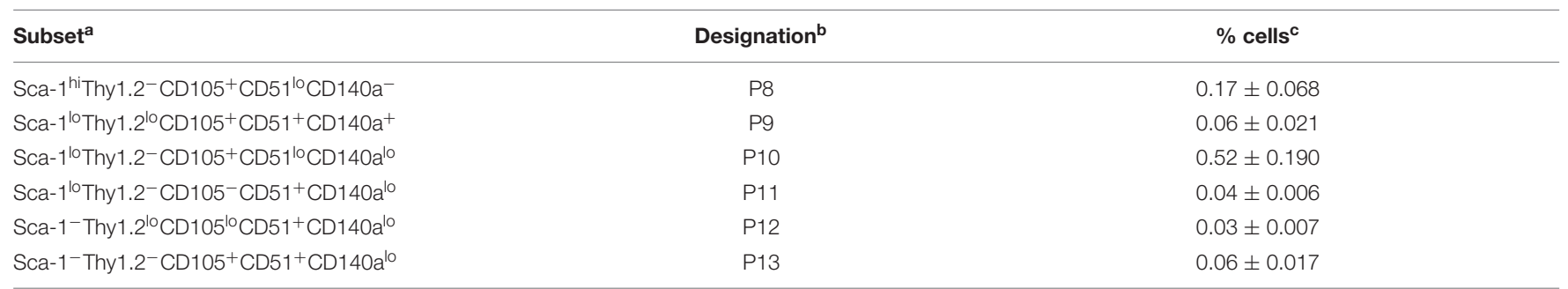

(B) Phenotype of cells cultured out of stromal subsets.

\begin{tabular}{|c|c|c|}
\hline Subset $^{b}$ & Cell number plated ${ }^{\mathrm{d}}$ & Phenotype of 28 day stroma ${ }^{e}$ \\
\hline P8 & $(2.8 \pm 0.5) \cdot 10^{4}(n=5)$ & No growth \\
\hline P9 & $(7.6 \pm 1.5) \cdot 10^{3}(n=5)$ & Sca- $1^{+}$gp $38^{+}{ }^{C D} 51^{10}$ CD $105^{-}$CD29 ${ }^{+}$ER-TR7-CD140a-Thy $1.2^{+}$ \\
\hline $\mathrm{P} 11$ & $(1.3 \pm 9.6) \cdot 10^{2}(n=5)$ & No growth \\
\hline
\end{tabular}

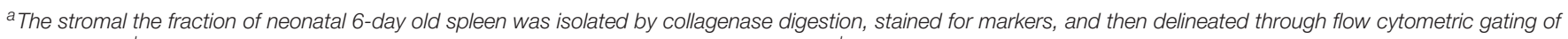

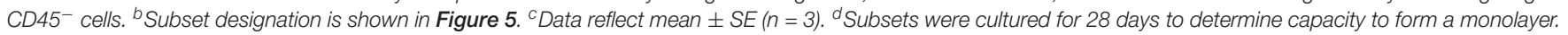
e Monolayers were trypsinised and cells stained with antibodies to determine phenotype flow cytometrically.

here on the growth and hematopoietic support function of stromal fractions (Table 3 and Figure 3). Stromal cells were prepared from 6 day old murine spleens using collagenase treatment and stained for identification of subsets. Live $\left(\mathrm{PI}^{-}\right)$, non-hematopoietic $\left(\mathrm{CD} 45.2^{-}\right)$stromal cells were first gated. Further analysis showed three distinct populations based on level of Sca-1 expression as Sca- $1^{\mathrm{hi}}, \mathrm{Sca}-1^{\mathrm{lo}}$ and Sca- $1^{-}$cells (Figure 5). These were subsequently analyzed for Thy1.2, CD105, 
TABLE 5 | In vitro hematopoietic support capacity of defined stromal subsets.

\begin{tabular}{|c|c|c|c|c|}
\hline Experiment $^{\mathrm{a}}$ & Test & Control & Relative yield in control ${ }^{b}$ & Yield test/control' \\
\hline 1 & gp38+ & $5 \mathrm{G} 3$ & 1.80 & 0.178 \\
\hline 2 & gp38+ & $5 G 3$ & 1.90 & 0.474 \\
\hline 3 & CD140a+ & $5 G 3$ & 2.68 & 0.119 \\
\hline 4 & CD140a+ & $5 G 3$ & 2.58 & 0.214 \\
\hline 5 & CD105+ & $5 \mathrm{G} 3$ & 1.80 & 0.044 \\
\hline 6 & CD105+ & $5 G 3$ & 1.48 & 0.083 \\
\hline 7 & P10 & 5G3 & 1.90 & 7.11 \\
\hline 8 & P10 & $5 \mathrm{G} 3$ & 1.96 & 0.280 \\
\hline 9 & P9 & 5G3 & 1.48 & 3.71 \\
\hline 10 & P9 & $5 \mathrm{G} 3$ & 0.51 & 2.75 \\
\hline Mean \pm SE & & & $1.81 \pm 0.18$ & \\
\hline
\end{tabular}

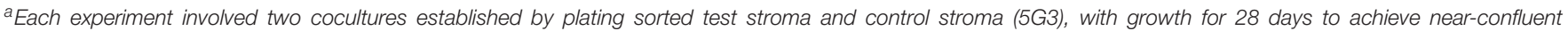

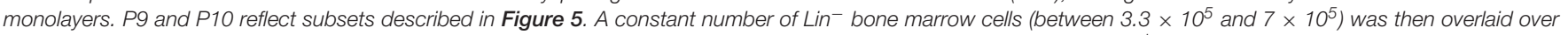

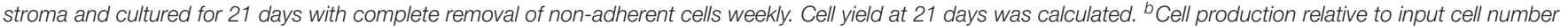
was constant for $5 \mathrm{G} 3 \mathrm{co}$-cultures. ${ }^{C}$ Cell production in test versus control (5G3) co-cultures was calculated for each experiment. Values >1.0 are shown in bold.

(B) Proportion of myeloid subsets produced in stromal co-cultures.

\begin{tabular}{|c|c|c|c|c|c|c|}
\hline & \multicolumn{2}{|c|}{$\% L^{-D C} C^{a, b}$} & \multicolumn{2}{|c|}{$\%$ cDC-like $e^{a, b}$} & \multicolumn{2}{|c|}{$\%$ Myeloid $^{\mathrm{a}, \mathrm{b}}$} \\
\hline & 1st Experiment & 2nd Experiment & 1st Experiment & 2nd Experiment & 1st Experiment & 2nd Experiment \\
\hline gp38+ & 81.0 & 86.9 & 0.14 & 0 & 18.9 & 13.1 \\
\hline CD140a+ & 75.1 & 65.6 & 0.08 & 0.03 & 24.8 & 34.3 \\
\hline CD105+ & 87.9 & 39.3 & 0 & 0.02 & 12.2 & 60.5 \\
\hline P9 & 58.5 & 47.8 & 0.03 & 0 & 41.2 & 52.6 \\
\hline P10 & 52.4 & 47.8 & 0.01 & 0.04 & 47.6 & 52.1 \\
\hline $5 \mathrm{G}^{\mathrm{C}}$ & \multicolumn{2}{|c|}{$90.5 \pm 1.77$} & \multicolumn{2}{|c|}{$2.63 \pm 1.42$} & \multicolumn{2}{|c|}{$7.02 \pm 0.41$} \\
\hline
\end{tabular}

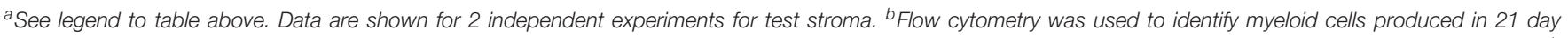

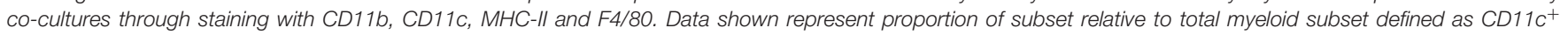
and/or CD11 $b^{+}$cells. ${ }^{C}$ Data for $5 G 3$ is shown as mean $\pm S E(n=5)$.

CD51 and CD140a expression. The Sca- $1^{\text {hi }}$ subset contained a single population (P8), while the Sca- $1^{\text {lo }}$ subset contained three populations (P9, P10, and P11) (Figure 5). The Sca- $1^{-}$subset contained two populations of interest (P12 and P13) (Figure 5). The proportional representation of these subsets amongst splenic culture was measured in three replicate experiments. P10 was the most predominant subset, although all were representative of $<1 \%$ of stromal cells in 6 day old spleens (Table 4). P9, P10, and $\mathrm{P} 11$ reflect cells expressing marker profiles similar to $5 \mathrm{G} 3$. Stromal subsets P8, P9, P10, and P11 were sorted from 6 day old spleen for further study. Only P9 and P10 grew in vitro and produced confluent stromal monolayers within 28 days. These cells expressed a common Sca- ${ }^{+}$gp $38^{+}$CD $29^{+}$Thy $1.2^{+}$ phenotype, no longer expressing detectable levels of the CD105 or CD140a markers used to isolate the starting population (Table 4).

Several stromal cell isolates including $\mathrm{gp} 38^{+}, \mathrm{CD} 140 \mathrm{a}^{+}$, $\mathrm{CD} 105^{+}$, P9 and P10 were sorted for direct comparison with 5G3 in terms of hematopoietic support capacity. Ten independent experiments compared hematopoietic support capacity of a test stroma in relation to $5 \mathrm{G} 3$ used as the internal control (Table 5).
Stromal cells were grown for 28 days to achieve minimal confluence and then stromal monolayers were overlaid with a constant number of $\mathrm{Lin}^{-}$bone marrow progenitors. Nonadherent cells produced were removed weekly at medium change. Cells removed at 21 days were assessed in terms of yield and phenotype of cells produced. 5G3 showed reproducible capacity to support hematopoiesis with an average $( \pm S E)$ yield relative to input cell number of $1.8 .1 \pm 0.18$ across 10 experiments (Table 5). Capacity of test stroma to produce hematopoietic cells was then calculated relative to production in control cocultures. The gp $38^{+}, \mathrm{CD}_{140 \mathrm{a}^{+}}$and $\mathrm{CD} 105^{+}$stromal fractions gave yields less than that of $5 \mathrm{G} 3$ co-cultures, with $\mathrm{CD}_{105}{ }^{+}$ stroma being a very weak supporter. Two P9 co-cultures gave cell yields $2.71 \times$ and $3.76 \times$ greater than $5 \mathrm{G} 3$ (Table 5). Two P10 co-cultures gave distinctly different yields of $7.11 \times$ versus $0.280 \times$, perhaps reflecting the outgrowth of variant stromal subsets as seen previously for CD29 ${ }^{+}$subpopulations (Figure 3). When cells produced in stromal co-cultures were assessed phenotypically, high numbers of L-DC and myeloid cells were represented with very few cDC-like cells. Only 
$5 \mathrm{G} 3$ produced cDC-like cells which were recently shown to resemble regulatory DC (Petvises et al., 2018). Each of the $\mathrm{gp} 8^{+}, \mathrm{CD} 140 \mathrm{a}^{+}$and $\mathrm{CD} 105^{+}$stroma were high producers of L-DC relative to myeloid cells resembling 5G3, although their overall cell yield was lower than 5G3. Both P9 or P10 stroma produced even numbers of L-DC and myeloid cells. All cocultures maintained a small population of $\mathrm{CD}_{11 b^{-}} \mathrm{CD} 11 \mathrm{c}^{-}$cells thought to contain myeloid progenitors and precursors (data not shown).

\section{DISCUSSION}

Traditionally, the spleen is viewed as an immune organ which also supports erythropoiesis (Mebius and Kraal, 2005; Cesta, 2006). However, the spleen also plays an active role in extramedullary hematopoiesis during times of stress, infection and inflammation (Cesta, 2006; Johns and Christopher, 2012; Yamamoto et al., 2016). In this study, we have studied steadystate spleen to better understand the composition of stroma, its heterogeneity and growth capacity with a view to assessing its ability to support hematopoiesis. The hypothesis tested here is that spleen contains perivascular reticular cells of mesenchymal lineage which support hematopoiesis. Results confirm that the spleen stromal population is highly heterogeneous, but contains subsets which resemble mesenchymal perivascular cells which secrete CXCL12 and SCF and can support hematopoiesis. Clearly spleen contains a mixture of stromal cells of different phenotype which serves to emphasize the complexity of the stromal network and its important role in hematopoiesis and immune response development. Previously this lab showed grafting of splenic stromal cells sorted on the basis of a single marker (Tan and Watanabe, 2014, 2018). Those grafts showed the presence of hematopoietic cells and full development of splenic architecture.

Stromal subsets have been assessed for morphology, phenotype, growth and hematopoietic support capacity. Stromal fractions depleted of cells expressing CD29, gp38, CD105, Thy1.2 or CD140a failed to establish monolayers in culture, identifying these as important markers of cells which can grow in vitro. Stromal cells that grow out of 28-day cultures consistently show a Sca- $1^{+}$gp $38^{+}$Thy $1.2^{+} \mathrm{CD} 29^{+} \mathrm{CD} 51^{+}$phenotype with some variability in expression of CD105 and CD140a, indicative of mesenchymal lineage cells readily expanded in vitro. However, caution needs to be exercised in regard to marker expression, since culturing conditions can lead to changes in surface maker expression (Pevsner-Fischer et al., 2011).

The co-culture assay involving overlay of $\mathrm{Lin}^{-}$bone marrow cells above 5G3 stroma has been extensively described (Periasamy et al., 2009; Periasamy and O'Neill, 2013; Petvises and O'Neill, $2014 b)$. Due to the low subset size of stromal fractions, and the need to culture stroma for 4 weeks to obtain enough cells for analysis of hematopoietic support capacity, it was difficult to gain reproducible data on hematopoietic support capacity for all stromal fractions. For this reason, a number of complementary experiments were attempted to sort and compare subsets of different marker phenotype. Overall the data confirmed hematopoietic support capacity for subsets resembling
5G3 stroma, with production of L-DC, myeloid cells and very few or no cDC-like cells in co-cultures. Exceptions were one of the subcultures of CD29 ${ }^{+}$stroma, one P10 stromal culture and the two P9 cultures. Stromal co-cultures also maintained a small population of progenitor/precursor cells within the

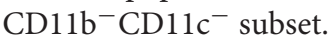

Heterogeneity within splenic stromal subsets appears to contribute to variability in hematopoietic support capacity and this is very evident for P10 stroma. One out of 2 stromal cultures of sorted P10 cells was a high cell producer. Given the relatively large size of the P10 subset amongst the stromal subsets identified in Table 4 and Figure 5, it is possible that P10 is heterogeneous, and that further markers or single cell sequencing analysis will be needed to identify stroma which are strong supporters amongst this subset. In contrast, two isolates of the very small P9 subset were very strong supporters of hematopoiesis. Data shown here are consistent with a model whereby specific stromal cells, perhaps defined by the P9 and P10 subsets identified here, have superior hematopoietic support function.

The variability in hematopoietic support noted in this study parallels that seen amongst clonal cell line derivatives of the original parental STX3 splenic stromal line (Despars and O'Neill, 2006a; Periasamy et al., 2009). In that study, cloned stromal lines derived from STX3, including 2A8, 5G3, and 10C9, were good but variable supporters, whereas 3B5 was a much weaker supporter (Periasamy et al., 2009). In this study, the equivalent in vivo Sca- $1^{+}$gp $38^{+}$Thy $1.2^{+} \mathrm{CD} 29^{+} \mathrm{CD} 51^{+}$stromal cell subset has been shown to grow in vitro and to support hematopoiesis. However, since the markers which define this subset are not lineagespecific, heterogeneity may still exist within this rare population. Analyses of growth capacity have indicated the importance of CD140a and CD105 as markers defining stromal subsets which can grow in vitro and show hematopoietic support. However, these were also found to be elusive markers showing variable and sometimes weak expression, perhaps subject to in vitro growth conditions.

While the main focus of the paper has been on identification of stromal cells which reflect perivascular reticular cells akin to those described in bone marrow, we have also confirmed that some stromal fractions have capacity to expand hematopoietic progenitors. We have so far been unable to study these progenitors in detail due to the small number of cells which can be collected from stromal co-cultures. Future work will concentrate on the very small P9 and P10 fractions and their capacity to support hematopoiesis. Recent studies now describe splenic stromal cells which act as niches for HSC under conditions of extramedullary hematopoiesis (Inra et al., 2015; Oda et al., 2018). However, these reports do not directly identify stromal cells nor do they test their capacity for supporting hematopoiesis. They are concerned with the contribution of spleen to hematopoiesis under stress conditions, and do not consider a role for spleen in hematopoiesis under steady state conditions in normal animals. This study contributes information on the stromal cell type which signals hematopoiesis in the steady-state, as well the myeloid cell types produced. The contribution of spleen to hematopoiesis is an 
important consideration particularly in regard to aging and HSC transplantation in clinical settings.

\section{ETHICS STATEMENT}

This study was carried out in accordance with the recommendations of the Australian Code for Care and Use of Animals for Scientific Purposes, 8th Edition (2013). Work was conducted according to protocol \# A2013/11 approved by the Animal Experimentation Ethics Committee of the Australian National University.

\section{AUTHOR CONTRIBUTIONS}

HL designed and performed the experiments, analyzed and assembled the data, and wrote and reviewed the manuscript. HO

\section{REFERENCES}

Akashi, K., Traver, D., Miyamoto, T., and Weissman, I. L. (2000). A clonogenic common myeloid progenitor that gives rise to all myeloid lineages. Nature 404, 193-197. doi: 10.1038/35004599

Cesta, M. F. (2006). Normal structure, function, and histology of the spleen. Toxicol. Pathol. 34, 455-465. doi: 10.1080/01926230600867743

Corselli, M., Chin, C. J., Parekh, C., Sahaghian, A., Wang, W., Ge, S., et al. (2013). Perivascular support of human hematopoietic stem/progenitor cells. Blood 121, 2891-2901. doi: 10.1182/blood-2012-08-451864

den Haan, J. M., Mebius, R. E., and Kraal, G. (2012). Stromal cells of the mouse spleen. Front. Immunol. 3:201. doi: 10.3389/fimmu.2012.00201

Deng, B., Deng, W., Xiao, P., Zeng, K., Zhang, S., Zhang, H., et al. (2015). Nonadherent culture method downregulates stem cell antigen-1 expression in mouse bone marrow mesenchymal stem cells. Exp. Ther. Med. 10, 31-36. doi: $10.3892 /$ etm.2015.2457

Despars, G., and O'Neill, H. C. (2006a). Heterogeneity amongst splenis stromal cell lines which support dendritic cell haematopoiesis. In Vitro Cell. Dev. Biol. Animal 42, 208-215. doi: 10.1290/0602016.1

Despars, G., and O'Neill, H. C. (2006b). Splenic endothelial cell lines support development of dendritic cells from bone marrow. Stem Cells 24, 1496-1504. doi: 10.1634/stemcells.2005-0530

Despars, G., Periasamy, P., Tan, J., Abbey, J., O’Neill, T. J., and O' Neill, H. C. (2008). Gene signature of stromal cells which support dendritic cell development. Stem Cells Dev. 17, 917-927. doi: 10.1089/scd.2007.0170

Dor, F. J., Ramirez, M. L., Parmar, K., Altman, E. L., Huang, C. A., Down, J. D., et al. (2006). Primitive hematopoietic cell populations reside in the spleen: studies in the pig, baboon, and human. Exp. Hematol. 34, 1573-1582. doi: 10.1016/j.exphem.2006.06.016

Fogg, D. K., Sibon, C., Miled, C., Jung, S., Aucouturier, P., Littman, D. R., et al. (2006). A clonogenic bone marrow progenitor specific for macrophages and dendritic cells. Science 311, 83-87. doi: 10.1126/science.111 7729

Hinton, R., Petvises, S., and O'Neill, H. (2011). Myelopoiesis related to perinatal spleen. Immunol. Cell Biol. 89, 689-695. doi: 10.1038/icb.2010.156

Inra, C. N., Zhou, B. O., Acar, M., Murphy, M. M., Richardson, J., Zhao, Z., et al. (2015). A perisinusoidal niche for extramedullary haematopoiesis in the spleen. Nature 527, 466-471. doi: 10.1038/nature15530

Johns, J. L., and Christopher, M. M. (2012). Extramedullary hematopoiesis: a new look at the underlying stem cell niche, theories of development, and occurrence in animals. Vet. Pathol. 49, 508-523. doi: 10.1177/03009858114 32344

Kiel, M. J., Yilmaz, M. H., Iwashita, T., Yilmaz, O. H., Terhorst, C., and Morrison, S. J. (2005). SLAM family receptors distinguish hematopoietic stem and designed the experiments, analyzed and interpreted the data, and wrote and reviewed the manuscript.

\section{FUNDING}

This work was supported by project grants to $\mathrm{HO}$ from the Australian Research Council (\#DP130101703) and the National Health and Medical Research Council of Australia (\#585443). HL was supported by an Australian National University Postgraduate Scholarship.

\section{SUPPLEMENTARY MATERIAL}

The Supplementary Material for this article can be found online at: https://www.frontiersin.org/articles/10.3389/fcell.2019.00001/ full\#supplementary-material

progenitor cells and reveal endothelial niches for stem cells. Cell 121, 11091121. doi: 10.1016/j.cell.2005.05.026

Kim, C. H. (2010). Homeostatic and pathogenic extramedullary hematopoiesis. J. Blood Med. 1, 13-19. doi: 10.2147/JBM.S7224

Lim, H. K., Periasamy, P., and O’Neill, H. C. (2018). In vitro murine hematopoiesis supported by signaling from a splenic stromal cell line. Stem Cells Int. 2018:9896142. doi: 10.1155/2018/9896142

Liu, K., Victora, G. D., Schwickert, T. A., Guermonprez, P., Meredith, M. M., Yao, K., et al. (2009). In vivo analysis of dendritic cell development and homeostasis. Science 324, 392-397. doi: 10.1126/science.1170540

Luther, S. A., Tang, H. L., Hyman, P. L., Farr, A. G., and Cyster, J. G. (2000). Coexpression of the chemokines ELC and SLC by T zone stromal cells and deletion of the ELC gene in the plt/plt mouse. Proc. Natl. Acad. Sci. U.S.A. 97, 12694-12699. doi: 10.1073/pnas.97.23. 12694

Malhotra, D., Fletcher, A. L., and Turley, S. J. (2013). Stromal and hematopoietic cells in secondary lymphoid organs: partners in immunity. Immunol. Rev. 251, 160-176. doi: 10.1111/imr.12023

Mebius, R. E., and Kraal, G. (2005). Structure and function of the spleen. Nat. Rev. Immunol. 5, 606-616. doi: 10.1038/nri1669

Mueller, S. N., and Germain, R. N. (2009). Stromal cell contributions to the homeostasis and functionality of the immune system. Nat. Rev. Immunol. 9, 618-629. doi: 10.1038/nri2588

Oda, A., Tezuka, T., Ueno, Y., Hosoda, S., Amemiya, Y., Notsu, C., et al. (2018). Niche-induced extramedullary hematopoiesis in the spleen is regulated by the transcription factor Tlx1. Sci. Rep. 8:8308. doi: 10.1038/s41598-018-26 693-x

O’Neill, H. C., Griffiths, K. L., Periasamy, P., Hinton, R. A., Petvises, S., Hey, Y. Y., et al. (2014). Spleen stroma maintains progenitors and supports longterm hematopoiesis. Curr. Stem Cell Res. Ther. 9, 354-363. doi: 10.2174/ 1574888X09666140421115836

O’Neill, H. C., Wilson, H. L., Quah, B., Abbey, J. L., Despars, G., and Ni, K. (2004). Dendritic cell development in long-term spleen stromal cultures. Stem Cells 22, 475-486. doi: 10.1634/stemcells.22-4-475

Periasamy, P., and O’Neill, H. C. (2013). Stroma-dependent development of two dendritic-like cell types with distinct antigen presenting capability. Ex. Hematol. 41, 281-292. doi: 10.1016/j.exphem.2012.11.003

Periasamy, P., Petvises, S., and O'Neill, H. C. (2013). Development of two distinct dendritic-like APCs in the context of splenic stroma. Front. Immunol. 4:73. doi: 10.3389/fimmu.2013.00073

Periasamy, P., Tan, J. K. H., Griffiths, K. L., and O’ Neill, H. C. (2009). Splenic stromal niches support hematopoiesis of dendritic-like cells from precursors in bone marrow and spleen. Exp. Hematol. 37, 1060-1071. doi: 10.1016/j.exphem. 2009.06.001 
Petvises, S., and O’Neill, H. C. (2014a). Characterisation of dendritic cells arising from progenitors endogenous to murine spleen. PLoS One 9:e88311. doi: 10. 1371/journal.pone.0088311

Petvises, S., and O’Neill, H. C. (2014b). Distinct progenitor origin distinguishes a lineage of dendritic-like cells in spleen. Front. Immunol. 4:501. doi: 10.3389/ fimmu.2013.00501

Petvises, S., Periasamy, P., and O’Neill, H. C. (2018). MCSF drives regulatory DC development in stromal co-cultures supporting hematopoiesis. BMC Immunol. 19:21. doi: 10.1186/s12865-018-0255-y

Pevsner-Fischer, M., Levin, S., and Zipori, D. (2011). The origins of mesenchymal stromal cell heterogeneity. Stem Cell Rev. Rep. 7, 560-568. doi: 10.1007/s12015011-9229-7

Roozendaal, R., and Mebius, R. E. (2011). Stromal cell-immune cell interactions. Annu. Rev. Immunol. 29, 23-43. doi: 10.1146/annurev-immunol-031210101357

Sugiyama, T., Kohara, H., Noda, M., and Nagasawa, T. (2006). Maintenance of the hematopoietic stem cell pool by CXCL12-CXCR4 chemokine signaling in bone marrow stromal cell niches. Immunity 25, 977-988. doi: 10.1016/j.immuni. 2006.10.016

Tan, J. K., and O’Neill, H. C. (2010). Haematopoietic stem cells in spleen have distinct differentiative potential for antigen presenting cells. J. Cell. Mol. Med. 14, 2144-2150. doi: 10.1111/j.1582-4934.2009.00923.x

Tan, J. K., and Watanabe, T. (2014). Murine spleen tissue regeneration from neonatal spleen capsule requires lymphotoxin priming of stromal cells. J. Immunol. 193, 1194-1203. doi: 10.4049/jimmunol.1302115
Tan, J. K. H., and Watanabe, T. (2018). Determinants of postnatal spleen tissue regeneration and organogenesis. NPJ Regen. Med. 3:1. doi: 10.1038/s41536-0180039-2

Tsuchiyama, J., Mori, M., and Okada, S. (1995). Murine spleen stromal cell line SPY3-2 maintains long-term hematopoiesis in vitro. Blood 85, 3107-3116.

Wilson, H. L., Ni, K., and O'Neill, H. C. (2000). Identification of progenitor cells in long-term spleen stromal cultures that produce immature dendritic cells. Proc. Natl. Acad. Sci. U.S.A. 97, 4784-4789. doi: 10.1073/pnas.08027 8897

Yamamoto, K., Miwa, Y., Abe-Suzuki, S., Abe, S., Kirimura, S., Onishi, I., et al. (2016). Extramedullary hematopoiesis: elucidating the function of the hematopoietic stem cell niche (Review). Mol. Med. Rep. 13, 587-591. doi: 10. 3892/mmr.2015.4621

Conflict of Interest Statement: The authors declare that the research was conducted in the absence of any commercial or financial relationships that could be construed as a potential conflict of interest.

Copyright (C) 2019 Lim and O'Neill. This is an open-access article distributed under the terms of the Creative Commons Attribution License (CC BY). The use, distribution or reproduction in other forums is permitted, provided the original author(s) and the copyright owner(s) are credited and that the original publication in this journal is cited, in accordance with accepted academic practice. No use, distribution or reproduction is permitted which does not comply with these terms. 